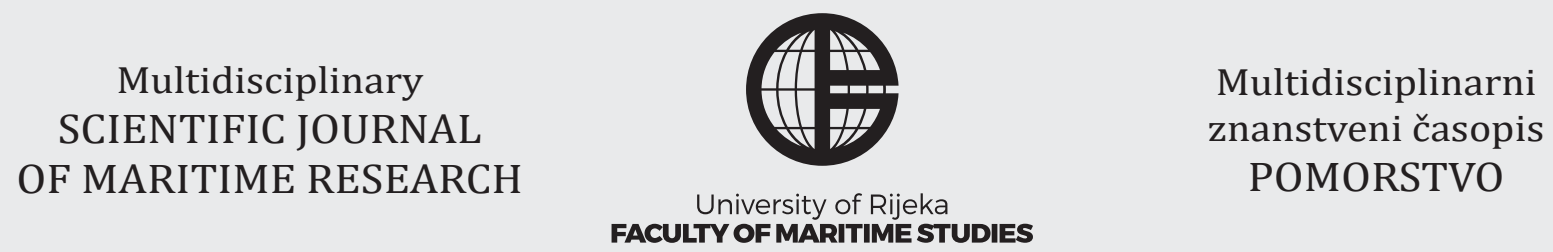

\title{
Global shipbuilding activities in the modern maritime market environment
}

\author{
Mirano Hess, Ivan Filip Pavić, Serdjo Kos, David Brčić
}

University of Rijeka, Faculty of Maritime Studies, Studentska 2, 51000 Rijeka, Croatia, e-mail: hess@pfri.hr; ivan.filip.pavic@gmail.com; skos@pfri.hr; brcic@pfri.hr

\begin{abstract}
The international trade, in the long run being influenced primarily by global economy, is hardly imaginable without maritime transport of goods. The investors in the shipping market, i.e. shipowners, foresee the key return of their capital investments through collection of the freight payments. Consequently, the position and ultimately survival of the owners is intensely influenced with the freight rate cycles, which in turn depend on demand and supply of ships. As historically proved, the higher the freight rates, the more orders for new ships are secured by shipyards. Most of the factors that impact shipowners' decisions, especially those related to placing the orders, thus extend their influence towards shipyards' operations and earnings. Competition among shipyards to ever attract more shipowners and secure more new orders or higher value orders, results in expanding their facilities, shortening delivery dates, making their ships' design more appealing, lowering prices, etc. Observing fluctuations of the market and understanding impact factors on the freight rates' segment and on shipbuilding segment therefore, is a crucial occupation accompanying executive decision making process for both, shipbuilders and shipowners. Recent state of the global shipbuilding industry is presented in this paper, based on the most recently available data on shipping market and on the global shipbuilding activities. Near-future outlook is given through analysis of the current market developments and industry potentials as well as with respect to the rivalry among competitors. Besides, clarification of market present state's impact factors is herein given and significant conclusions for their current development and future perspectives are addressed, considering available information.
\end{abstract}

\section{ARTICLE INFO}

Preliminary communication

Received 5 November 2020

Accepted 2 December 2020

Key words:

Shipping industry

Freight rates

Shipbuilding

Newbuilding prices

\section{Introduction}

The maritime shipping market could be defined as a system of relations between shipowners and transport users that is between the supply of shipping space and the demand for that space, to transport the cargo or passengers. The segments of the maritime market are the newbuilding market, the sale and purchase market, the demolition market and the freight market [3]. The main driving forces behind the maritime market are the world economy and trade [3].

The main characteristic of the maritime market is expressed through the cyclical movement of freight rates and ships' prices. The most significant earnings are the revenue from freight rates, which will depend on the bal- ance between the current supply and the demand for the ships. In a situation where the supply of ships is less than the demand for it, the freight rates will rise. Shippers decide to buy ships on second hand market, delay the sale of old ones and order new ships to make the most in the period of high rates. Thus, high rates reflect in high prices for the new and second-hand ships.

The global economy achieved good results in 2018 with an increase of $3.6 \%$, while maritime trade, as an important branch of the world economy mechanism, fell from $4.2 \%$ in 2017 to $3.1 \%$ in 2018 [10]. Total cargo transported reached 10.7 billion tonnes. The global Gross Domestic Product (GDP) registered the highest growth since 2011 with a growth rate of $3.6 \%$ [16]. The United Nations Conference on Trade and Development (UNCTAD) 
predicted a positive future for maritime trade, with a $3.8 \%$ year-on-year increase from 2019 to 2023 . However, the global economy has deteriorated in 2019 and so has the demand for maritime transport. Given concerns about slowing growth in key economies, including China and the EU, and the possibility that the US-China trade dispute could escalate into a global trade conflict, growth was slowed in 2019 and beyond through 2020.

Due to many external influencing factors and unforeseen shocks, prediction of the market future movement, however, may prove as a risky business. In the geopolitics segment, along with the US-China trade dispute, there is also OPEC+ negotiations that have been deteriorating, resulting in the intensified output of oil from Saudi Arabia in April 2020, flooding the market with crude oil and lowering its market price. As a consequence, the crude oil tanker spot freight rates and time charter rates have ascended considerably. On the other hand, the coronavirus has added further pressure, in the Q1 of 2020, on the shipping industry and to already weak demand for the global fleet (except crude oil tankers). Consequently, many shipowners may now be looking to have their ships demolished. The global human cost due to the coronavirus pandemic has risen, and the required security initiatives have a significant effect on economic development. As a consequence of the pandemic, the world economy is expected to fall dramatically by $-3 \%$ in 2020, far worse than in the 2008-09 financial crisis [10]. Moreover, the IMO 2020 sulphur cap, being among major impacts, at the begging of the 2020, has influenced further freight rates decrease, particularly in the dry bulk and container sectors. The low demand and fleet overcapacity have been reflected on the shipbuilding industry, through less orders for new buildings. At the same time, China and the rest of Far East have lowered output of newly built ships from their shipyards due to the restrictions aimed at containing the virus spreading further.

This paper focuses on analysis and correlation of the recent and current market states in the shipbuilding and freight segments. It further gives an overview of the market's development, taking into account economy, trade, freight rates and shipbuilding indices. The data and information used have been compiled from various officially published sources. The trends and problems of the market are highlighted and discussed throughout the paper. Impact of various influencing factors on freight rates cycle and on new orders in shipbuilding is analysed and discussed. Competitiveness of the major shipbuilding nations/regions has been emphasized. In the following text, a literature review has been given, followed by an overview of the freight rates segment and the analysis of the shipbuilding segment in different countries/regions with concluding discussion and remarks.

\section{Literature review}

There are various studies on shipbuilding industry and related markets, some of which are cited. In the paper [13] the authors suggest a systematic ship development planning cycle by evaluating development planning activities carried out in major South Korean shipyards. In addition, it recommends an assessment structure and an appraisal program to test production planning on the basis of an automated production planning cycle. The evaluation framework consists of the stage of planning and the stage of operation in the company.

The study [4] offers a thorough overview of existing situation and the effect of the global crisis on the shipbuilding industry. The study outlines market aspirations for the shipbuilding sector based on predictions from the global economy.

[14] The authors suggest the shipbuilding industry to clarify subsequent shifts in leadership. The window of opportunity for Japan to step ahead of the United Kingdom was the introduction and usage of modern technology, a process referred to as the welding block. The study further discusses the peculiar structural existence of the origins of the incumbent trap in the shipbuilding industry, which varies from that identified with the perceived costs and advantages of modern versus old technologies.

Mathematical relationships that enable forecasting of the expected sale price of new container ships, based on data on vessels constructed in 2005-2015, are presented in [3]. The provided approximations render it possible to predict the price on the basis of the deadweight capacity or the number of containers the ship can carry.

The main determinants of new-built vessel price fluctuations and how the freight rate is influenced are studied in [5]. Empirical studies have shown that freight rate variability is the most significant and supportive determinant of new building price stability in capesize, panamax, handymax and handysize sectors. Shipyard capability transition, exchange rate fluctuations and shipbuilding cost variability are main determinants for certain ship types, whereas second-hand ship price fluctuations is not the key determinant for any ship type.

For the first time, the price formation of Chinese dry bulk carriers is discussed on the basis of historical shipbuilding contract costs. The outcome indicates that the time charter rate has the most important positive effect on the shipbuilding price; the rise in three other parameters, namely the cost of the shipbuilding, the price-cost margin and the usage of the shipbuilding capacity, have a positive influence in the descending order [2].

The paper [21] suggests a strategy to get the industry closer to lean manufacturing in terms of flow and provides a measure to assess how near the shipyard framework is to the optimal flow. The foundation for implementing lean thinking in shipbuilding is the correct deployment of group technologies by the usage of a product-oriented job breakdown framework.

In the paper [18], the author points out that it is fair to evaluate and predict the performance of the maritime shipbuilding industry in accordance with those relevant to 
the continued activity of these ships. The paper reveals the details of evaluating the utility of expenditure in the development of public seagoing ships (or transactions on a secondary market) from the investor's point of view.

The interfirm cooperative strategies of shipbuilding firms are investigated in [20]. This paper aims to understand the system nature and dynamics of interfirm cooperative strategies adopted by firms in the shipbuilding industry related to the phase of the shipbuilding cycle. A theory-building approach from case studies, based on interviews with managers of the Norwegian, Danish, Polish and Ukrainian shipbuilding firms, is applied in this study.

In [17] a simple model for estimating newbuilding costs is presented. Regression equations are estimated on a large data set of 2003-2007 shipyard deliveries reported in Lloyd's Shipping Economist. The equations developed in this paper can be used in a wide variety of economic analyses involving new ship construction and operating costs.

The existing situation of the Croatian shipbuilding industry [8] is addressed on the basis of the most recent available data on global and domestic shipbuilding operations and significant assumptions and proposals for its potential growth are drawn in the light of the current state of the world's shipping and shipbuilding databases. Potential possibilities are discussed through analysis of current negotiation potential of suppliers and buyers.

The authors [23] carried out a quantitative study of the historical and present condition of the shipbuilding industries in Croatia and Russia. The paper tried to recognize common issues for both countries' shipbuilding industries, as well as their national characteristics. The authors concluded that, in order to retain a leadership role on the global market, there is a need for flexibility in the reaction towards the changes in the global environment, throughout due time, expect changes in the priorities of the importing countries and seek to maintain the existing business networks and to build and improve one's role in the emerging markets.

\section{Freight rates considering different ships}

In 2016 the Baltic Dry Index (BDI) fell to its lowermost value since introduction [22], reflecting the positon of freight rate as well as world economy cycles, see graph 1. The dry bulk market began to recover in 2017 and that trend continued through 2018. Compared to the 2017 (graph 2), the average freight rates of bulk carriers are thus up about $25 \%$ from the end of 2018. Freight rates for Capesize ships averaged USD 19,283/day, for Panamax USD 13,048/day, Supramax USD 12,859/day and for a Handysize USD 10,266/day [9]. BDI continued to strengthen in April 2019 as the ongoing resumption of industrial activities in China led to improved demand for ships. However, in the first quarter of 2020, the index fell more than $40 \%$ as the rapid spread of coronaviruses around the world leads to shipment restrictions and weakened demand for dry bulk carriers.

Container charter rates, compared to 2016, when they reached record lows, continued to recover during 2018. Rates remained just over operating costs in 2018, averaging 69 against 55 in 2017 as per Alphaliner Charter Index [1]. Hence, to maintain rate control, shipowners have united in a small number of major alliances. The share of unemployed fleets has increased to 0.6 million TEU [2]. Depending on the size of the ship, prices ranged from USD 6,510 to USD 10,250 per day. For example, for a ship with a capacity of 2,000 TEU, the freight rate was USD 8,900/ day, a $24 \%$ increase over 2017 [9]. Transhipment of containers in Asia increased only $0.6 \%$ from 2018 to the next year, in contrast to $4 \%$ increase in 2017 and 2018. The main reasons for such slow growth are US-China trade dispute and global slowdown. Further decrease of the volume

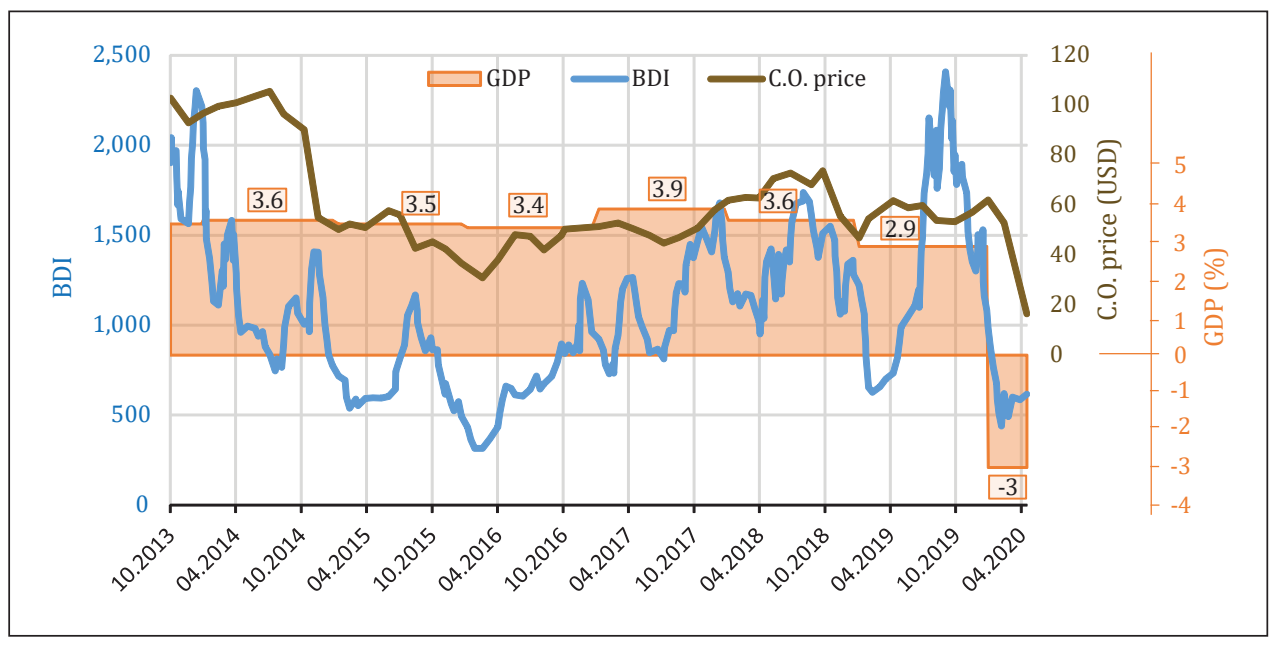

Graph 1 Baltic Dry Index (BDI), World Gross Domestic Product (GDP) and Crude Oil Price (C.0. Price) in the period from 10.2014 to 04.2020 


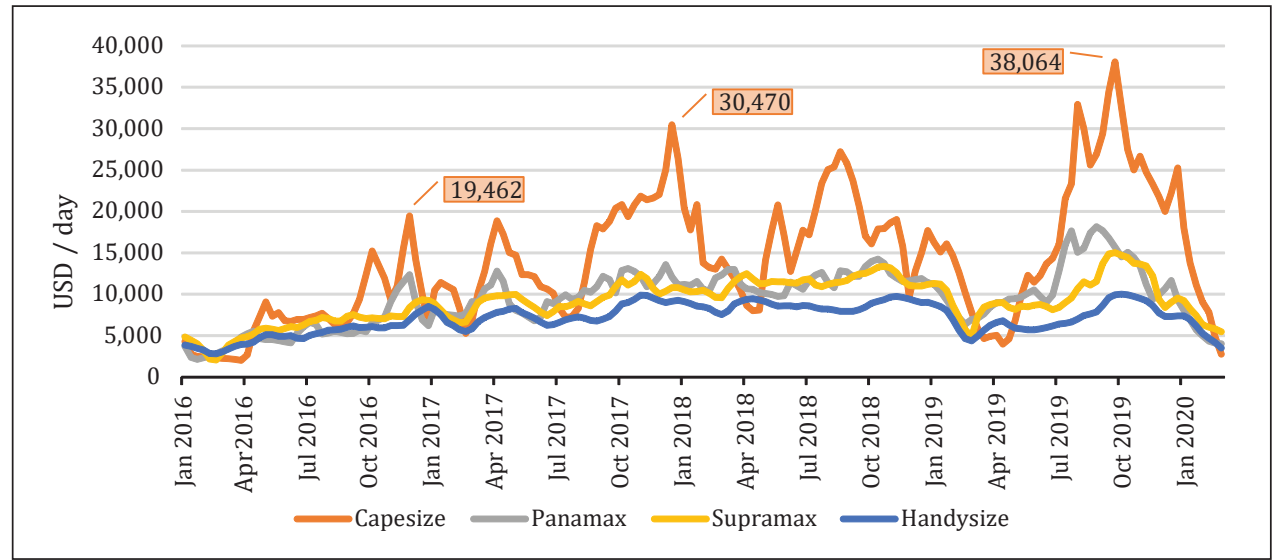

Graph 2 Dry bulk earnings 2016 to 2020

Source: Authors based on Tradewinds and Bloomberg data

of 2020 compared to 2019 is indicated by the negative effect of coronavirus on production in the region, as shown by the 2020 first quarter indices.

In 2018, tanker freight rates were in a lot of pressure [22]. The Baltic Clean Tank Index (BCTI) averaged 577 for petroleum products. In the crude oil sector, the Baltic Dirty Tanker Index (BDTI), with quite a fluctuation throughout the year, maintained an average value of 796 at the end of the year [15], indicating that crude oil rates have declined slightly since the beginning of 2018. However, as the price of oil has been constantly changing, so have the rates. They rose sharply at the end of 2018 as the price of oil fell by more than $40 \%$. China's imports from Iran decreased to 14.8 million tonnes in 2019 , more than half the level reached in the previous year. However, they imported from Saudi Arabia 26.7 million tonnes of oil, making it $47 \%$ more in 2019. Prices for both Long Range tankers, LR1 and LR, peaked in the last week of 2019. In early 2020 , the rates of petroleum freight rates had fallen.

At the end of the first week in February, the average earnings for Handysize tanker were USD 19,089 per day and for an MR tanker USD 12,552 [22]. Daily rates for the LR1 and LR2 tankers dropped to USD 7,161 and to USD 9,568 respectively. Time charter rates have slowly increased from 2018 to September 2019, when rates have improved rapidly and remained high until the end of 2019. They eventually fell because the world economy didn't justify such a rates development and also, the market was oversaturated with the ships' supply. By the end of March 2020, the one-year TC rate for VLCC reached USD 58,802 per day. Nonetheless, experts anticipate that rates will go down together with the oil demand during the rest of 2020 [15].

\section{The world fleet - recent development}

At the beginning of 2018, the world merchant fleet numbered 94,171 vessels, which together accounted for
1.92 billion tonnes dwt [16]. The total capacity of the world fleet thus increased by $3.31 \%$ according to data from the end of 2017 compared to 2016 when the increase was $3.15 \%$. The rise of the fleet, with the growing demand, has led to increase of the rates and thus the profit for shipowners. The sizes of the ships are constantly growing and so is the value of the fleet. Investments in new technologies and the demands of new regulations also add the value of the global merchant fleet [24].

Bulk carriers are the leading carriers with $42.5 \%$ of the world's total capacity in 2018. They are followed by tankers with $29.2 \%$ of the total capacity and by container ships with $13.1 \%$. Although they represent a smaller percentage of the world's capacity, container ships transport higher value cargoes than tankers and bulk carriers, ensuring that more than half of the monetary value of maritime trade belongs to them [24].

In addition to these three categories, general cargo, chemicals and gas vessels should also be mentioned. Thus, general cargo ships are the only one declining, at only $3.9 \%$ of the total world carrying capacity. One of the main reasons for this is the accelerated development of containerization, which is taking over the increasing traffic of goods. As for gas carriers, they are up 7.2\%, with further growth expected. The reason for this is the use of propulsion gas in the near future, which is considered to be a cleaner source of energy. Chemical carriers have also seen a slight increase, primarily due to high demand for chemicals in industrial production with about $4.1 \%$ of the total world's fleet capacity [16].

Expressed in GT, the total world fleet has grown steadily in the last decade, from 83,070 thousand at the beginning of 2009 to 133,364 thousand at the beginning of 2019. Comparing the fleets by GT, bulk carriers make up the largest share, about $34 \%$ of the total world fleet since 2012 (graph 3).

New ships' orders was already down before the coronavirus 2020 outbreak and has continued as the outbreak 


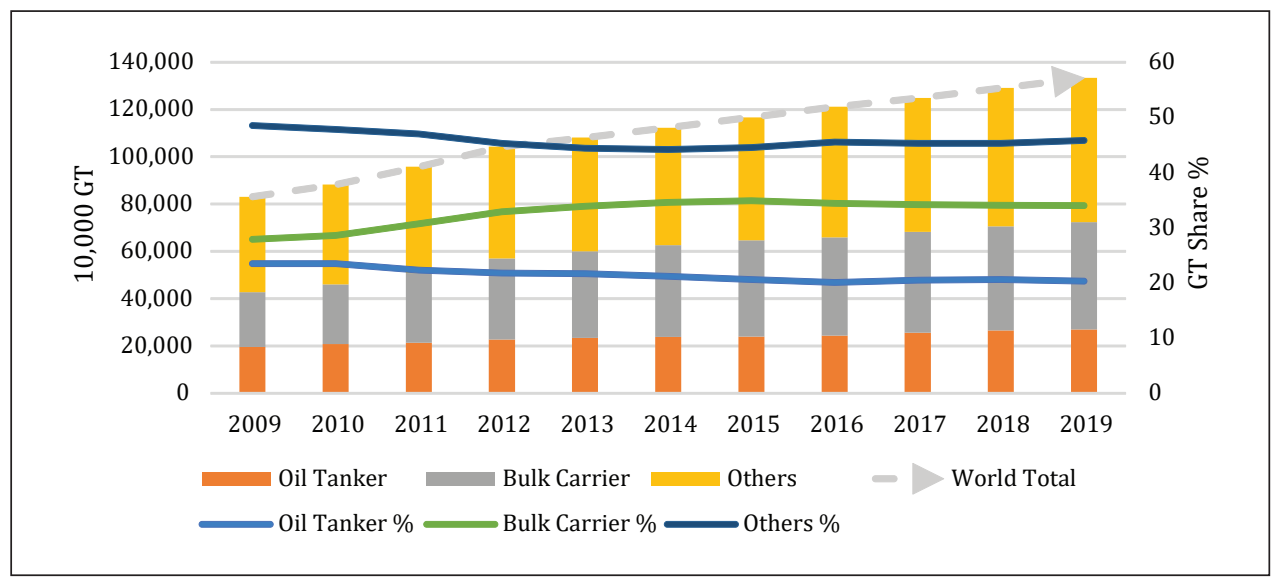

Graph 3 World fleet development 2009 to 2019 (Beginning of year. Ship Size Coverage 100 GT and over. Bulk carrier includes combined carriers. Oil tanker does not include chemical tankers and gas tankers but other liquids.)

Source: Authors based on IHS Markit "World Fleet Statistics”, 2019 “World Shipbuilding Statistics”, Tradewinds and Bloomberg data

has spread. Compared to first quarter of 2019, with 14.7 million dwt of new ships ordered from shipyards, the first quarter of the 2020 recorded only 6.7 million dwt, which is $55 \%$ lower from the previous year. Despite various downside factors in the past though, the world fleet has increased continuously since 1990, reaching in 2019 38,452 ships 1,935 million dwt [16].

\section{The world's shipbuilding and newbuilding prices}

Considering new orders in 2019, the largest share took South Korea with $41.87 \%$, followed by China with $32.92 \%$ and Japan with $16.17 \%$. Europe had $4.51 \%$ and the rest of the world, $4.53 \%$ [A4]. Due to the oil market movement throughout the 2019 [15], demand for tankers increased significantly, so were their freight rates [22]. On the other side, since demand for container ships, bulk carriers and special ships has dropped in 2019, world newbuilding orders weakened from 93.8 million dwt to 73.3 million dwt compared to 2018. The newbuilding prices, however, didn't shrunk much, due to already low prices and increased shipbuilding and steel costs, as measured by shipyards. Furthermore, new regulations certainly place additional pressure on shipbuilding process and shipbuilders' earnings. Due to higher demand, prices lowered less for takers than other ships, i.e. container and bulk ships.

Newbuilding orders gradually improved, from 2016 (32.6m dwt), to 79.2 million dwt in 2018 , to 97.6 million dwt in 2019. The world orderbook by the end of 2019 rose up to 201.4 million dwt. China, South Korea and Japan hold $95 \%$ of the global orderbook by deadweight and continues to compete throughout 2018-2020. China holds $45.4 \%$ of market share in 2019, followed by South Korea with $28.1 \%$ and Japan with $22 \%$. The rest of the world took $2.6 \%$ and Europe $1.9 \%$ deadweight share of the global orderbook in 2019 [7].
In periods of high demand the prices of new buildings are increasing, which is particularly favourable for shipyards, while at the moment when demand is saturated prices fall up to a whopping $90 \%$. Generally, there is a correlation between deliveries and orders, so when the number of orders surpasses deliveries, prices tend to rise. Number of orders in 2018 is on a slight increase over the previous years, especially driven by the bulk carriers' high demand, which also leads to a slight increase in the prices of new buildings [16]. Tendencies in contracting appear to head changes in the price indices [10]. Though, developments in contracting are more volatile than changes in the indices for second hand and particularly newbuilding prices.

In 2018, demand for container carriers, specialised ships and bulkers increased and receded for tankers. Due to this extra demand, shipbuilders have been able to raise prices by up to $10 \%$, which also allowed them to meet the increased cost of steel and the demands of new regulations. Owners, on the other hand, were struggling with the increased newbuilding prices as well as the deadline to comply with IMO 2020 regulations. The need for more efficient and compliant fuels threatens the existing fleet of ships in a way that a certain part of it will become commercially and technically old, which will require their replacement with new ships, thus increasing the cost of new buildings due to the increased orderbook [2].

The contracting activity of new ships as well as the prices of new buildings indicate the state of the shipbuilding industry [12]. Although the prices of new ships differ with regard to various factors, Clarkson's Index indicates the total price movement of the new buildings with upward trend [16].

Average prices of new bulk carriers were in a slight increase, ranging from 1.2 to $3.6 \%$. So a new Capesize $(180,000 \mathrm{dwt})$ ship was worth about USD 50 million, by the end of 2019, and a new Panamax (81,000 dwt) USD 
28 million. Prices for new Handymax (62,000 dwt) and Handysize $(38,000 \mathrm{dwt})$ ships ranged between USD 24 million and USD 26 million in the same period.

Prices in the tanker market were also increasing slightly, ranging from 1.2 to $3 \%$. The price of the new VLCC tanker $(320,000 \mathrm{dwt}$ ) was USD 92.5 million on the opening of 2020 . The new Suezmax category tanker $(157,000 \mathrm{dwt})$ was worth USD 60.5 million, and the new Aframax tanker (115,000 dwt) USD 48 million.

In the container shipping market, the average prices of new vessels are slightly higher, from 1.8 to $5 \%$. A new container vessel with a capacity of 13,000 TEU units is worth USD 115 million, while a vessel with a capacity of 2,750 TEU units is worth USD 35 million. The highest prices are achieved by new liquefied gas vessels, i.e., 174,000 m3 LNG vessel was worth USD 182 million.

\subsection{China}

In 2018, China positioned on the first place in ship orderbook. More specifically, number one in all shipbuilding segments: the orderbook with $43 \%$ of market share, newbuilding orders with $35 \%$ of market share and deliveries with $44 \%$ of market share [19]. Of the total of 117 active shipyards 10 made $72 \%$ of total orders. In the dry bulk sector China is by far the number one with $70 \%$ of the world's orderbook. In segments of tanker and container ships, China is in second place. At the same time a decrease is registered in other zones: $\mathrm{S}$. Korea, Europe and the rest of world, except Japan that in segment of new orders secured outstanding $90 \%$ increase.

Despite the best figures in the world, consolidation, restructuring and bankruptcies were present in China's shipyards, just like in the rest of the world. In 2018, two Chinese shipyards went in bankruptcy, which were earlier recorded in the White List reference.

Long-lasting restructuring of the Qingdao Yangfan Shipbuilding, entered into bankruptcy protection in 2016, has successfully finished. The situation was resolved in a way that it was completely bought out by another group. China Shipbuilding Industry Corp (CSIC) got initial consent from China's state council to reunite China State Shipbuilding Corp (CSSC). In that way, CSIC and CSSC would have more sales capacity than all of the South Korean shipbuilders united and a greater order reserve than any other shipbuilding corporation in the world. Japan's Mitsui E\&S Shipbuilding (MES) and Mitsui \& Co entered into the corporation with China's Yangzijiang Shipbuilding (YZJ Group), hence joining MES' technological strength, Mitsui's sales capabilities, and Yangzijiang's building expertise.

Hudong Zhonghua and MOL signed in 2018 an order for the world's largest LNG bunkering vessel that would supply LNG fuel to the world's largest 23,500 TEU container ship under construction at Hudong Zhonghua and SWS for CMA CGM. It can be noted that Japanese owners showed increasing interest for Chinese yards. In 2018 they have contracted 65 orders in China, containing 46 bulkers, 13 container carriers, five tankers and one LNG bunker carrier. Of the major orders and deliveries in 2018, several can be distinguished. Shanghai Waigaoqiao Shipbuilding acquired an order for two Vista-class luxury cruise vessels from CSSC Carnival, a joint venture between Chinese state-owned CSSC and the Carnival Group. In the Dalian Shipbuilding China's first LNG bunkering vessel is ordered. Shandong Shipping secured dry bulk order for 10 Capesize bulkers $(180,000 \mathrm{dwt})$ with the Germany's RWE.

Chinese shipyards have completed 880 ships or 2,304 thousand GT, making $38.8 \%$ of the world total share in 2019. The stated amount of GT is close to the achieved figures in the previous years, 2017 and 2018, with 2,383 and 2,315 thousand GT, respectively. However, due to the shipbuilding cycle position, those figures are not even close the ones from years 2011 and 2012, with 3,961 and 3,900 thousand GT of completed ships [7].

Considering orderbook by the end of 2019, Chinese shipyards are again positioned on the top of world scale

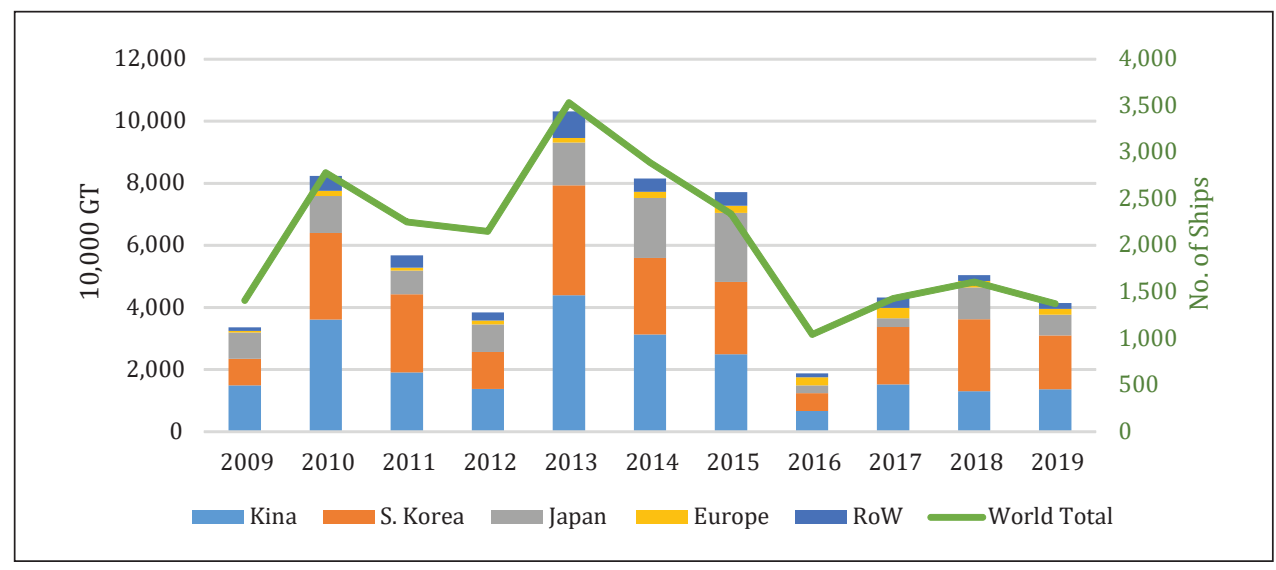

Graph 4 New ship orders 2009 to 2019 (Ship Size Coverage 100 GT and over.) 
with 1,520 ships of 5,041 thousand GT. New ship orders, secured by Chinese shipyards in the last decade, compared with the other leading countries/regions is illustrated by graph 4.

To rationalize China's shipbuilding industry, in the light of current and predicted future newbuilding market, their government supported foundation of two new big shipyards CSSC and CMHI. Jiangnan delivered to CMA CGM the first ultra large container carrier of 23,000 teu, with dual fuel (LNG/diesel) propulsion. The same company also ordered 15 containerships of about 15,000 teu with LNG propulsion.

Beginning of April 2020, COSCO Shipping have ordered eight 62,000 dwt open hatch bulk carriers at COSCO Dalian for delivery from the end of 2021. This follows a similar order from China Merchants at Jinling Shipyard at the end of March. China Merchants Energy Shipping have ordered four firm $62,000 \mathrm{dwt}$ open hatch bulk carriers at Jinling (a China Merchants group shipyard). Delivery of the series is due in 2022.

\subsection{South Korea}

South Korea is the second largest shipbuilding nation in the world in 2018, with an orderbook of $63.8 \mathrm{~m} \mathrm{dwt}$, accounting for $27.5 \%$ of the market share and with $26 \%$ market share in newbuilding orders. In tonnage output it ranks third, behind Japan. The number of orders is $20 \%$ higher than previous year, but $5 \%$ less by deadweight. During 2018, South Korea secured orders for 65 large LNG vessels, and almost $55 \%$ of all orders related to container ships [19]. They remained the market leader in the tanker market with $63 \%$ of orders. Of the entire orders in 2018, $92 \%$ went to the three largest shipyards: HHI (Hyundai Heavy Industry) with $46 \%$, DSME (Daewoo Shipping and Maritime Engineering) with $29 \%$ and Samsung with $17 \%$ [2].

DSME is the largest shipyard in the world. Equipped with excellent and only the latest equipment, it special- izes in the construction of structures of all kinds, from merchant ships, special purpose vessels, to off-shore platforms and wells. It covers an area of 4.9 million square meters, with about 35,000 employees. The entire complex is located in Okpo Bay on the southeast coast of the Korean Peninsula [6].

Another interesting fact is that South Korea also has the largest group, Hyundai Heavy Industries, with about $13.3 \%$ of the world's orderbook [9]. The Hyundai shipyard extends over four kilometres along Mipo Bay in Ulsan. It consists of numerous branches specializing in various fields, from off-shore industries, industrial plants, engines and machinery. HHI-EMD (Engine \& Machinery Division) holds a $30 \%$ market share in the production of diesel engines, both for marine and other purposes. The group also leads the tanker market with eco-friendly designs [9].

During 2018, South Korean shipyards recorded several significant orders. For example, 65 large LNG carriers, of which 25 for HHI, 20 for Samsung and 20 for DSME. HMM (Hyundai Merchant Marine) ordered 20 large containerships from the "Big Three", of which eight with capacity of 15,300 TEU at HHI, seven with total capacity of 23,000 TEU at DSME and five with 25,000 TEU at Samsung. This order is supported by Korea Ocean Business Corp (KOBC), controlled by state. Hyundai Mipo Shipyard secured an order for 12 feeder containerships for Japanese shipowner, while H-line shipping took orders for three LNG-fuelled Capesize bulkers from HHI.

In 2018, there were three major shipbuilders that dominated the industry, SHI (Samsung Heavy Industries), DSME (Daewoo Shipbuilding \& Marine Engineering) and SHI (Samsung Heavy Industries). However, severe reorganisation of the South Korean shipbuilding industry persists, including labour and capacity cuts, closures and lay-offs. Government and national banks pushed all the shipyards to reduce building capacity, to cut costs and to union into just two dominant South Korean shipbuilders.

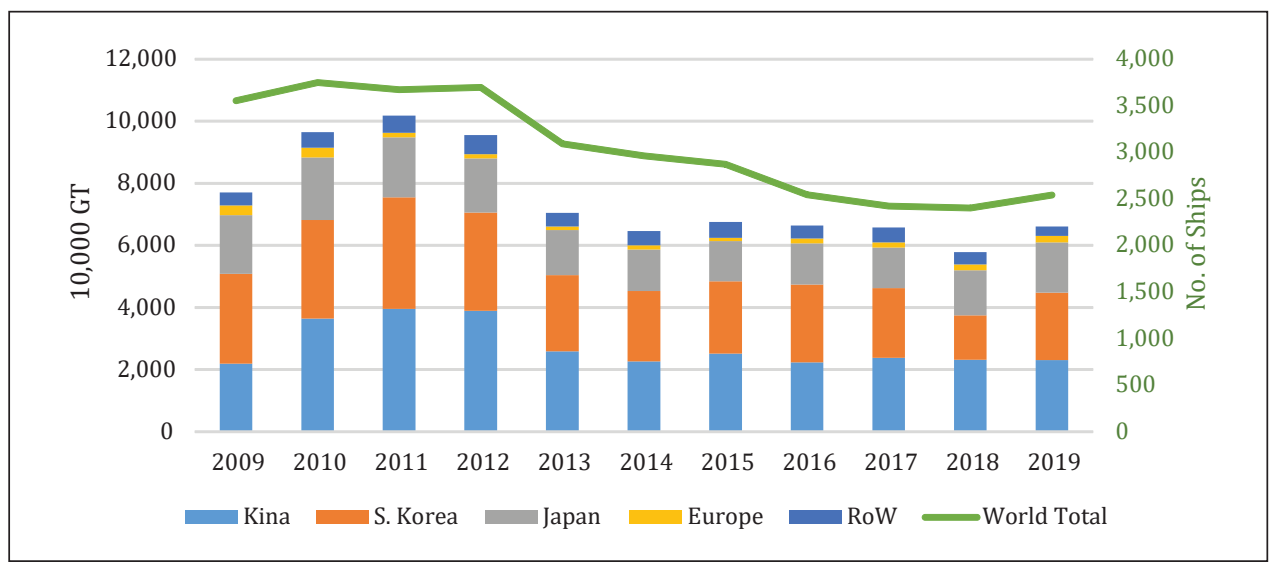

Graph 5 New ships' completions 2009 to 2019 (Ship Size Coverage 100 GT and over.) 
South Korean shipyards ranked second in 2019 on the scale of World Ship Completions, with 2,174 thousand GT constructed or 239 ships (graph 5). Thus, Koreans have returned to the figures close to those of 2014-2017, in contrast to the 1,432 thousand GT completed in 2018. The orderbook, by the end of 2019 reads 4,076 thousand GT or 457 ships.

In March 2020 Hyundai Mipo announced orders for a total of seven 50,000 dwt methanol carriers funded by Waterfront Shipping (part of Methanex). Pan Ocean placed order, in March 2020, to DSME for a single 300,000 dwt VLCC due for delivery in $3 Q 2021$. Hyundai Heavy took an order from Union Maritime for one firm plus one optional 91,000 cbm VLGCs with the first to be delivered in Q1 of 2022. MOL placed order for one ship and NYK, Meiji and Marinvest each ordered two ships, which will be delivered from end of 2021 onwards.

\subsection{Japan}

Japan was firmly in third place in world shipbuilding with $29.9 \%$ of the market share and orderbook of 55.5 million dwt in 2018. Comparing to year 2017, new orders has doubled and the order-to-delivery ratio remains stable. Demand remained high for bulk carriers, tankers and container vessels and Japan is still an important player in the segment of bulkers with orders of $14.2 \mathrm{~m}$ dwt in 2018 [19]. Of the 35 Japanese shipyards that secured orders in 2018, there were three largest yards (Imabari, Oshima and JMU) which took $75 \%$ of the orders [2].

In competition with China and South Korea, Japan's shipyards are losing customers. Japanese shipowners, who have always respected domestic shipbuilding, are forced to build in neighbouring countries due to lower costs and earlier time of delivery. This situation even led to a conflict, in which Japan complained to the WTO World Trade Organization) alleging that Korea was contravening freemarket values by subsidizing shipbuilders with loans from the state investors and agencies for credits export.

Spanish shipping company Elcano placed an order in 2018 to Imabari for two LNG carriers, the first ever built in Japan that uses the membrane Mark III Flex containment system. Imabari also secured 17 neo-Panamax containerships of 11,000 TEU from Shoei Kisen Kaisha, ships owned and chartered by parent organization, Imabari Shipbuilding.

With 493 ships built, of 1,621 thousand GT, Japanese shipyards took third position on the scale of world ship completions in 2019. By the end of the same year the orderbook shows 674 ships of 2,255 thousand GT. Kawasaki Heavy Industries have, in the first week of 2020, contracted a single $84,000 \mathrm{cbm}$ VLGC with Iino (for Equinor) due for delivery in $2 Q 2022$. Imabari, JMU and Oshima, Japan's largest shipyards secured $11.6 \%$ of the total orders.

The ratio between the current orderbook and yearly output lowered from 2.8 at the end of 2018 to 1.8 at the end of 2019. It is interesting to mention that Oshima and Namura will build the first 95,000 deadweight LNG-fuelled panamax bulkers.

Due to the overcapacity, Kawasaki Shipbuilding Heavy Industries, one of the shareholders of NACKS and DACKS is shutting down $30 \%$ of capacity at its main shipyard in Sakaide, Japan. In order to transfer some of its capacity to more profitable submarket, Mitsubishi Heavy Industries plans to turn its Nagasaki shipbuilding facility into a cruise ship construction and repair yard. Some discussions have been taking place at Imabari Shipbuilding and Japan Marine United to build an alliance, with the intention to combine forces when it comes to design for various types of ships and improve their efficiency in the tight market.

\subsection{Europe}

In contrast to shipyards from the Far East, European shipyards are oriented towards the construction of more sophisticated ships. They are much smaller in surface area and usually have one large dry dock and one goliath portal crane [A1]. European shipyards had an increase in orders of $37 \%$ over 2017 , driven primarily by demand for cruise ships. There were a few more orders for bulk carriers and ferry boats. A total of 36 new cruise ships were ordered, of which 20 were awarded to the three largest construction sites, Fincantieri, Meyer Werft and Chantiers de l'Atlantique. The other 16 orders were distributed throughout the shipyards across Europe. European shipyards are thus firmly in the market for cruise ships, and the orderbooks for the aforementioned shipyards extend until 2027 [7]. Comparison of European orderbook, expressed in GT, with the other counties/regions, over the last decade is given by graph 6 .

The ranking of European shipyards by dwt produced, shows that Russia and Spain hold $50 \%$ of the orderbook. If other leading countries are added to this, then 7 of them hold a total of $87 \%$ of the market across Europe [11]. Russia was therefore in the first place, mainly thanks to orders from local companies such as Rosneft and Sovcomflot. A total of 1.5 million dwt were entered in the orderbooks in 2018. Star Far Eastern Shipyard placed an order for five new tankers, all by a local investor.

The Italian shipyards were in second position mainly thanks to the Fincantieri Group, which is also the largest group in Europe. Spain dropped to third position in 2018 with four delivered Suezmax tankers from Navantia Shipyard for a local shipowner. Germany hold fourth place with several high-value contracts for cruise ships. Germany's largest Meyer Werft shipyard had $2.3 \%$ of the world's orderbook.

Romania ranked fifth in the orderbook. Their largest Daewoo Mangalia shipyard became Damen Shipyards Mangalia after Daewoo Shipping sold its $51 \%$ ownership of Damen Shipyard to the group in 2018. With this agree- 


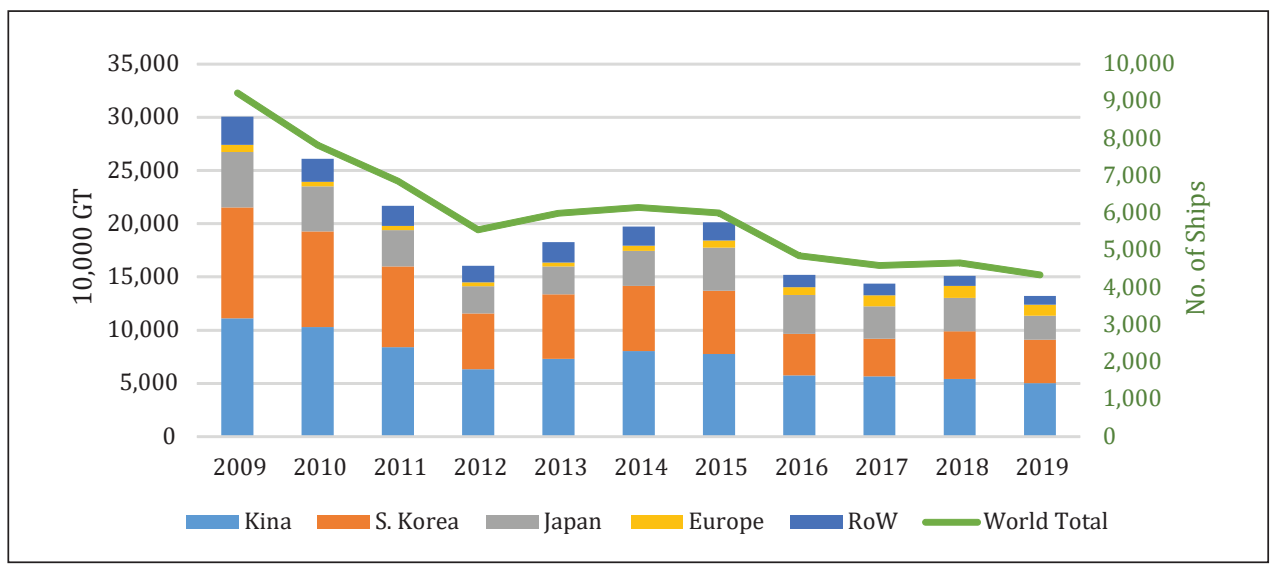

Graph 6 Orderbook at Year-end 2009 to 2019 (Ship Size Coverage: 100 GT and over.)

Source: Authors based on IHS Markit "World Fleet Statistics”, Tradewinds and Bloomberg data

ment, the Romanian government was left to control interest and the Damen group had operational control over the shipyard.

Despite the political situation, Turkey ranked sixth in Europe with 12 orders in 2018, mostly ferries. The Netherlands hold the seventh place thanks to 12 smaller orders, namely general cargo ships by Arklow Shipping at Ferus Smith Shipyard and 7 orders at Royal Bowedes Shipyard.

Croatian shipbuilding has fallen from a third place in Europe, which it held for several years, to eighth in 2018. 6 vessels, with a total value of USD 4.2 million, were contracted, of which one ship was delivered and two partially equipped hulls. The whole situation around Croatian shipbuilding is not positive. Uljanik group is on the verge of collapse. Due to the inability to pay both bank debts and workers, subcontractors and suppliers, several ships under construction were cancelled, including two Ro Ro's and a livestock transport vessel. Several unfinished ships and cancelled orders also enter the story. There were 27 ships in orderbook by February 2019, to be delivered from 2019 to 2023 [11]. It was announced, at the beginning of 2020, that Croatia's DIV Group had entered into a preliminary agreement to take over Kleven Verft from Hurtigruten.

The STX France shipyard changed its name to Chantiers de l'Atlantique, as it used to be. The ownership is divided into several parties, the state has $84 \%$, the Naval Group $12 \%$, local suppliers $1.6 \%$ and workers $2.4 \%$. It is currently in the process of being taken over by the Fincantieri Group, allowing them to own a majority of the ownership. Only the shipyard has a completed orderbook until 2027.

In the case that European shipyards are ranked by ship value, the leading countries would be Italy, Germany, France and Finland. This indicates that European shipbuilding is based on the orders of high value ships. This is due to the large number of contracted cruise ships, of which European shipyards own $95 \%$ of the world orderbook for this category of ships.

On the basis of GT ranking in 2019, Italy retained its first position amongst European shipbuilding nations, mainly because of its shipbuilding group Fincantieri, the largest cruise ship builder in the world with a total of 37 large units to be delivered before 2027. Fincantieri finalized the take-over of its affiliate Norwegian group Vard.

France is positioned on second position thanks to its leading shipyard Chantiers de l'Atlantique, $84.3 \%$ owned by the French State. The shipyard took 5 cruise ship orders in 2019 and now has total orderbook of 13 large cruise units to be delivered before 2027 .

Germany was ranking third on the basis of GT in 2019. Meyer Werft is one of the best shipbuilders in the world for cruise vessels. They delivered MV AIDAnova at the end of 2018, the largest and cleanest cruise ship ever built in Germany. It is the world's first ever ocean liner with an LNG drive system. Two sister ships are ordered and will follow in 2021 and 2023.

\subsection{The rest of the world}

Orderbooks for shipyards in the rest of the world (RoW) jointly fell by $20 \%$ in 2018, from 11.3 million dwt at the end of 2017 to 8.9 million. New construction orders also fell, by $50 \%$, while deliveries remained stable. According to these figures, the ratio between orderbook and delivery has dropped to 1.9 from 2.3 for 2017 [2].

of the 12 shipyards that secured new orders, only four shipyards accounted for $97 \%$ of the total orderbook. These are Hanjin Subic and Tsuneishi Cebu in Philippines, CSBC - Taiwan and Hyundai Vinashin - Vietnam.

Shipyards from the Philippines thus remained the leading among those from the RoW with $49 \%$ of all orders. However, Hanjin Subic Shipyard was trying to save itself by restructuring after they ended up with USD 400 million 
in bank loans in 2018. The Philippine government was ready to help in conjunction with another investor, among whom two Chinese groupings have shown interest.

Vietnam retained the second position, in a way that $99 \%$ of new orders were due to the Hyundai Vinashin Shipyard. In addition to this shipyard, there is only one other operating company in Vietnam that is in the hands of foreign investors. All other shipyards in the Vietnam area went bankrupt [2].

Taiwan is in third position after signing 14 new contracts, mainly for the construction of container ships. Brazil's shipyards have not signed a new contract since 2016. Bangladesh is in the sixth position thanks to the ordering of three new general cargo vessels and 60 more sections to be completed. Seaworld Express Ferry placed an order, in the first week of April 2020, to Incat (Australia) for a single 700 pax/79 car high speed catamaran for delivery in early 2022.

In 2019, the orderbook of RoW shipyards went down to 5.2 million dwt from 7.4 million dwt in 2018, thus making their market share having dropped from $3.3 \%$ to $2.6 \%$. In comparison with 2018, when RoW delivered 4.6 million dwt, in 2019 only 3.5 million dwt was delivered. The radio between the orderbook and yearly output shrank to 1.5 in 2019 against 1.9 in 2018. One of the main reasons for such a shrinkage is fall of Hanjin Subic shipyard in 2019, which recorded $30 \%$ of RoW new orders in 2017. Furthermore, CSBC of Taiwan, another great contributor did not manage to secure orders in 2019 despite accounting for $50 \%$ of RoW new orders in 2018.

Tsuneishi Cebu (Philippines) with $56 \%$ and Hyundai Vinashin (Vietnam) with $33 \%$ of new orders, make together $89 \%$ of all new orders secured in RoW, by the end of 2019. Thus, the Philippines remains the leader of the Rest of the World shipbuilding group, with $41.4 \%$ of the total orderbook, despite the collapse of Hanjin Subic.

Vietnam retained its second position in 2019 thanks to Hyundai Vinashin which owned $99.7 \%$ of the orderbook. Taiwan retained its third place due to orders secured by CSBC back in 2018, however in 2019, there were no new orders. Eisa Ilha, shipyard in Brazil is the only one in this country that has 7 ships in orderbook, although no new orders have been secured since 2016. Bangladesh now has an orderbook of 53 units under construction at 8 different shipyards and is positioned on fifth place. Singapore has an orderbook of 6 ships, 3 small ferries at Sembcorp Marine and 3 small LNG carriers at Keppel Singmarine and Sembcorp Marine.

\section{Discussion and conclusion}

Most of the goods, in international trade, being moved between sellers and buyers pass through the maritime transport, as the cheapest form of transportation. The shipbuilding industry as a crucial market segment in the maritime and world trade, therefore needs to fulfil all the requirements regarding the demand for available space, to meet the various conditions of transportation and international regulations so that these goods can smoothly flow from the manufacturer to the buyer.

To understand how the industry operates, monitoring and knowledge of a number of factors are required, i.e. recent state of the world economy, and demand and supply of the shipping space to have an overview and eventually predict the near-future cycle movement. Furthermore, it is important to monitor the existing world fleet capacity and ageing development in order to anticipate the necessary and timely replacement of the fleet.

Monitoring and understanding freight rates' fluctuations and factors that influence cycle movement is crucial in shipowner's decision making process when placing a newbuilding order or buying a second hand ship. Compliance with the existing and forthcoming maritime regulations is a driving force which a shipowner has to take into account and make an integral part of his business policy, especially when deciding on investing into reviewing or expanding his fleet. Since shipyards differ in their facility availability, delivery dates, facility position, prices and design speciality, shipowner has to make decision on which shipyard to take into consideration.

This paper has therefore, focused on an analytical overview of the recent state of the shipping market, including freight rate and shipbuilding segments, on which basis an investor can make (short term) investment strategy.

Container ships' owners are once again pushed to the border of their operational sustainability, mainly due to the low container shipping rates at the beginning of 2020, which are in the range of the past five years rates and additional fuel costs from IMO 2020. Experts anticipate the container shipping fleet to grow by $2.5 \%$ in 2020 . Since the expected growth in demand is lower, container shipping market will once again depreciate in 2020.

In contrast to the solid fourth quarter of the 2019, as often is the case with the winter seasonality, freight rates of the dry bulk sector have decreased on the begging of the 2020. This drop has been supported by the extra cost of fuel as a result of the IMO 2020 sulphur cap. Experts were estimating that dry bulk shipping demand for 2020 will be around $2 \%$. That would be a rise of about $1 \%$ compared to $1 \%$ growth in 2019 . However, lower demand rate than the one previously anticipated, after coronavirus outbreak, seams now more realistic. Adding to this the expected increased costs associated with compliance to the 2020 sulphur cap, will make some shipowners struggle to cover even their ships'/fleet's operational costs and some potential investors in shipping to look for prosperous business investments elsewhere. On the other side, considering present state of the world shipbuilding orderbook, the world fleet growth, hence the supply of ships will be significantly higher than the demand side.

Freight rates for oil product tankers have tumbled as well in 2020, with larger vessels earning less than smaller 
ones. Rates for both LR tankers peaked in the last week of 2019. However, by the end of the first week of February 2020, LR1 and LR2 tankers were earning "only" USD 7,150 and USD 9,570, respectively. At the same time average earnings for an MR tanker were about USD 12,530 per day and those for Handysize about USD 19,110 per day.

In 2019, 29.7 million dwt of new oil tankers were delivered to the market and only 3.5 million dwt were demolished. Older ships were kept on the market in anticipation of demand boost from the IMO 2020 sulphur cap regulations. The same regulations being the reason for new orders placed by shipowners in the past and their vessels being delivered to the market throughout 2019, thus making $6.2 \%$ fleet growth. Experts estimate much lower crude oil tanker fleet growth in 2020 of only $1.8 \%$.

Last couple of years, especially 2018 and 2019 are marked with uncertainty and consolidation in the shipbuilding industry, the trend that seems to continue in 2020. In the first half of 2018, about 10 million dwt of newbuilding orders were placed each month. This figure considerably plunged in the following period and remained at the rate of about 5.5 million dwt throughout 2019. The main causes for lower ordering rate are geopolitical instability, relatively high newbuilding prices and new IMO regulations coming into force.

Geopolitical instability and fear of a further intensification in the trade dispute between USA and China has put some of the owners to "standby and think" instead of "ordering" position. Besides, widening disparity between newbuilding prices and earnings resulting from price increases that prevailed in 2017 and 2018 has further made owners cautious to invest in the fleet. There has also been growing uncertainty within the shipping industry as it prepared for the introduction of the global $0.5 \%$ sulphur cap on marine fuels.

As opposed to the rapid growth in number of world shipyards, particularly on the Far East in the first decade of the millennium, shipbuilding nations turned to rationalize shipyards capacity through mergers and bankruptcies during the last couple of years. The aim of this restructuring is making the industry economically viable, profitable and capable of offering innovative and competitive equipment/ships' designs demanded by fast changing market. Nevertheless, newbuilding orders gradually developed, from 2016 (32.6m dwt), to 79.2 million dwt in 2018, to 97.6 million dwt in 2019. The world orderbook by the end of 2019 rose up to 201.4 million dwt. It is important to notice here the extent at which the shipping industry is subject to the euphoria of the masses and how easily the industry is enthusiastic and commits to massive investments even on a short-lived shift in opinion in the freight sector.

The three Asian major shipbuilding nations, who together hold more than $95 \%$ of the world's orderbook measured in tons deadweight, continue to compete for a greater market share. China holds $45.4 \%$ of market share in 2019, followed by South Korea with $28.1 \%$ and Japan with $22 \%$. The rest of the world took $2.6 \%$ and Europe $1.9 \%$ deadweight share of the global orderbook in 2019. The trend in foreseeable future seems to be realistically expected, although on the other side persistent funding problems and difficulties in collecting equity or acquiring long-term jobs in the shipping sector to raise income seems to be continuing throughout 2020 and beyond.

However, bearing in mind that coronavirus has imposed a wide range of issues to shipping market, particularly to ship managers, and considering the IMF forecast scenario of $3 \%$ global GDP decline for 2020, even lower of that of 2008 financial crisis, the prospect for the rest of 2020 and 2021 doesn't look bright. Furthermore, it should be noted the impact of the coronavirus on the shipping fleet through delays of new-built ships across the Far East, i.e., Chinese shipyards delivered in March 2020 only half of the dwt compared to the same period in the previous year.

As fluctuations of the freight indexes and ship ordering cycle movement have impact on the other maritime market segments, in the next research it would be a logical continuation to analyse the relationship and compare ships' second hand and recycling segments with the ships' freight and new buildings' segments.

\section{References}

[1] Alphaliner Weekly Newsletter Volume 2019 Issue 28 \& 50, and AXSMarine, https://public.axsmarine.com/resources/ Alphaliner_Monthly_Monitor_2018_01.pdf?cb= 1542341959. (accessed 23.03.2019)

[2] BRS Group, Shipping and shipbuilding markets, Annual Review, 2019; https://www.brsbrokers.com/. (accessed 28.04.2019)

[3] Cepowski, T. (2016). Projecting sale prices of new container ships built in 2005-2015 based on dwt and teu, Scientific Journals of the Maritime University of Szczecin, 48(120): 171-175, doi: 10.17402/191.

[4] Cornel, G., Filip, N., Catalin, P. (2013). Crisis Effects on Shipbuilding Market, Ovidius University Annals, Economic Sciences Series, Ovidius University of Constantza, FES, 0(2): 31-34.

[5] Dai, L., Hu, H., Chen, F., Zheng, J. (2015). The dynamics between newbuilding ship price volatility and freight volatility in dry bulk shipping market, International Journal of Shipping and Transport Logistics, 7(4): 393, doi: 10.1504/ IJSTL.2015.069666.

[6] DSME, 2019, The World's Premium Shipbuilding and Offshore Company, https://www.dsme.co.kr/epub/introduction/introduction0101.do. (accessed 17.04.2019)

[7] EMSA, The world merchant fleet - statistics from Equasis, http://www.emsa.europa.eu/equasis-statistics/items. html? cid=95\&id=472. $($ accessed 21.04.2020).

[8] Hadzic, N., Tomic, M., Vladimir, N., Ostojic, S., Senjanovic, I. (2015). "Current State and Perspectives of the Croatian Shipbuilding Industry". Journal of Naval Architecture and Marine Engineering, Vol. 12, No. 1.

[9] Hyundai Heavy Industries, 2019, World's largest builder of marine diesel engines, http://english.hhi.co.kr/biz/engine_ over. (accessed 18.04.2019) 
[10] International Monetary Fund, World Economic Outlook, April 2020: The Great Lockdown, https://www.imf.org/en/ Publications/WEO/Issues/2020/04/14/weo-april-2020. (accessed 22.04.2020)

[11] Jadranbrod d.d., Hrvatska Brodogradnja, Svjetsko brodograđevno tržište - studeni 2018

[12] Jiang, L., Lauridsen, J.T. (2012). Price formation of dry bulk carriers in the Chinese shipbuilding industry, Maritime Policy Management, 39(3): 339-351.

[13] Lee, J. M., Jeong, Y., Woo, J. H. (2018). Development of an evaluation framework of production planning for the shipbuilding industry, International Journal of Computer Integrated Manufacturing, 31(9): 831-847, doi: 10.1080/ 0951192X.2018.1449968.

[14] Lim, C., Kim, Y., Lee, K. (2017). Changes in industrial leadership and catch-up by latecomers in shipbuilding industry, Asian Journal of Technology Innovation, 25(1): 61-78.

[15] MacroTrends, WTI Crude Oil Prices - 10 Year Daily Chart, https://www.macrotrends.net/2516/wti-crude-oil-prices10-year-daily-chart. (accessed 23.04.2020)

[16] IHS Markit, World Fleet Statistics, https://ihsmarkit.com/ products/maritime-world-fleet-statistics.html. (accessed 13.04.2020)
[17] Mulligan, R.F. (2008). A simple model for estimating new building costs, Maritime Economics\&Logistics, 10(3): 310321, doi:10.1057/mel.2008.8.

[18] Ogay, S.A., Investing serial sea shipbuilding, Region: Economics and Sociology, Institute of Economics and Industrial Engineering of Siberian Branch of RAS, 2011, 4.

[19] OECD, Shipbuilding Market Developments Q2, 2018.

[20] Solesvik, M.Z. (2011). Interfirm collaboration in the shipbuilding industry: the shipbuilding cycle perspective, International Journal of Business and Systems Research, Inderscience Enterprises Ltd, 5(4): 388-405.

[21] Storch, R.L., Lim, S. (1999). Improving flow to achieve lean manufacturing in shipbuilding, Production Planning \& Control, 10(2): 127-137.

[22] Trading Economics, BDI data, and Ukragroconsult.com, available at: http://www.blackseagrain.net. (accessed 22.04.2020)

[23] Tulyakova, Irina R. Dengov, Victor V. Gregova, Elena (2019). The Positions of Russia and Croatia Shipbuilding Products on World Markets and Prospects of Co-Operation (Analytical Overview), "Naše more" 66(3) - Supp., pp. 13-21.

[24] UNCTAD, Review of Maritime Transport, 2019, available at: https://unctad.org/. (accessed 17.01.2020) 